\title{
Patterns of major photosynthetic pigments in freshwater algae. 2. Dinophyta, Euglenophyta, Chlorophyceae and Charales
}

\author{
M. Schagerl ${ }^{1 *}$, C. Pichler ${ }^{1}$, Karl Donabaum² \\ ${ }^{1}$ Institute of Ecology and Conservation Biology, University of Vienna, Althanstraße 14, A-1090 Vienna, Austria. \\ 2 Donabaum \& Wolfram OEG, Zentagasse 14, A-1050 Vienna, Austria.
}

\begin{abstract}
Major pigment patterns of 18 chlorophyceae, 7 charales, 4 euglenophyta, and 2 dinophyta isolated from freshwater ecosystems, were investigated by means of HPLC. In this study, quantitative results are presented, too, which are capable for phytoplankton quantification techniques based on pigment patterns. Chlorophyceae revealed a pattern similar to that of higher plants, but in some strains, loroxanthin as well as $\alpha$-carotene were present. In charophytes, except for vegetative specimens of $C h a r a$ tomentosa, $\gamma$-carotene was detected in antheridia only. Among investigated freshwater euglenophytes diadinoxanthin was the major carotenoid, with neoxanthin and B-carotene present in minor amounts. Besides chlorophylls-a and -c, dinophytes contained high quantities of peridinin, whereas fucoxanthin was absent. An unknown component eluting just before violaxanthin showed a spectrum reminding of peridinin.
\end{abstract}

Keywords : HPLC, freshwater algae, pigments, carotenoids, dinophyta, euglenophyta, chlorophyta, chlorophyceae, charophyceae.

\section{Introduction}

In algal pigment studies, abundant marine phytoplankton, i.e. picoplanktonic cyanoprocaryota, diatoms, coccolithophorids, and dinoflagellates (Round 1985, Sommer 1998), have attracted the most interest, so far (e.g. Mantoura \& Llewellyn 1983, Wright \& Shearer 1984, Gieskes \& Kraay 1986a, b, Klein \& Sournia 1987, Roy 1989, Veldhuis \& Kraay 1990, Kohata \& Watanabe 1991, Roy et al. 1996, Latasa et al. 1997, Goericke 1998). In contrast to marine communities, freshwater phytoplankton is often dominated by chlorophytes, synurophyceae and diatoms, with hypertrophic conditions favoring cyanoprokaryotes and, in case of organic pollution, also euglenophyta (Round 1985).

Aside from a few studies, often dating back several decades, detailed analyses of pigment patterns are virtually non-existent for the vast majority of the freshwater algae. Pigments of stoneworts, for instance, ha-

\footnotetext{
* corresponding author : michael.schagerl@univie.ac.at
}

ve only been sporadically investigated (Seybold et al. 1941, Andrews et al. 1984, Howard-Williams et al. 1995, Schagerl \& Pichler 2000). Charophyceae, closely related to higher plants and including the orders zygnematales, coleochaetales, klebsormidales, and charales, are typical of freshwater environments (Lee 1999), save for Chara canescens DES. et LoISELEUR IN LIOS.-DESLONGCHAMPS which is characteristic of brackish habitats (Krause 1997). Charales likely show a pigment pattern similar to that of higher plants, but one speciality is the occurrence of $\gamma$-carotene. Beside charophyceans, a second major lineage of green algae exists containing trebouxio-, ulvo- and chlorophyceans. Both these two lineages are thought to have arisen from the polyphyletic prasinophyceans (Graham \& Wilcox 2000). Primary habitat of ulvo- and prasinophytes are marine ecosystems, whereas trebouxiophyceans are dispersed chiefly in terrestrial habitats. Chlorophyceae, which are part of this study, are primarily found in freshwater or terrestrial systems. Despite an basic agreement between pigment pattern of chlorophyceans and higher plants there exist some peculiarities like the occurrence of loroxanthin in some algal species. Within the volvocales, Schagerl \& Angeler 
(1998) and Schagerl et al. (1999) found the photosynthetic pigment loroxanthin to be a potential taxonomical marker. Their results stress the necessity of analyzing more than one strain per taxon, as it turned out, that in Pandorina morum (MÜLLER) BORY as well as in Eudorina elegans EHRENB. some strains do posses loroxanthin, whereas others do not. In these studies, sequencing of the internal transcribed spacer regions confirmed the hypothesis that both Pandorina morum and Eudorina elegans actually consist of several lineages and thus are not single biospecies in their own right.

The euglenoids, typical of freshwater habitats, probably originate from the ingestion of green algal chloroplasts by kinetoplastids (van den Hoek et al. 1993, Lee 1999). The majority of euglenoids is heterotrophic, only $30 \%$ of the known genera possess chloroplasts (Graham \& Wilcox 2000). Aside from the polyphyletic group of prochlorophytes, pigmented euglenophyta are the only class of algae to contain chlorophyll-b (chl-b), but their general pigment pattern more closely resembles that of the heterokontophyta, due to the presence of diadinoxanthin and diatoxanthin (Rowan 1989). Quantitative results of euglenoid pigment contents are published sporadically, but no detailed data are given (Mackey et al. 1996).

Major caroteniod among phototropic dinophyta is peridinin, which is part of the light harvesting complex II (LHC II ; Häder 1999). In some species, peridinin amounts to $85 \%$ of the total carotenoid content. Carotenoids produced by dinoflagellates are more complex than carotenoids of other algae (Young \& Britton 1993). In marine species, which represent about $90 \%$ of all known dinophycean taxa (van den Hoek et al. 1993), also 19'hexanoyloxyfucoxanthin, a fucoxanthin-derivative, and fucoxanthin were found (Mandelli 1968, Bjornland \& Tangen 1979, Young \& Britton 1993).

This study adds to the knowledge of pigment patterns of freshwater algae. For multivariate approaches on algal quantification by means of pigments like multiple linear regression (eg. Woitke et al. 1996, Descy et al. 2000) or factor analysis (Mackey et al. 1996, Wright et al. 1996, Descy et al. 2000, Ansotegui et al. 2001), basic data sets of carotenoid contents are required. Some quantitative pigment data are contributed in the present study. Special attention was given also to methodological considerations as to the type of detector used for analysis (diode array detectors versus spectrophotometer).

\section{Materials and methods}

Organisms were taken from the culture collection of algae at the Institute of Ecology and Conservation Biology at the University of Vienna (Kusel-Fetzmann \& Schagerl 1992, Table 1). The unialgal, non-axenic batch-clones were cultured at $20^{\circ} \mathrm{C}$. Growth was established using a light:dark regime of $14 \mathrm{~h}$ white light (30 $\mu \mathrm{mol}$ photons $\mathrm{m}^{-2} \mathrm{~s}^{-1}$ ) and $10 \mathrm{~h}$ darkness. Several clones were grown in parallel cultures. Charales were harvested from different freshwater habitats in Eastern Austria and transferred to the laboratory immediately. Prior to extraction, specimens were carefully rinsed. To test the variability of carotenoids per unit chl-a, data sets of chlorophycean continuous cultures with varying nutrient supply (original $\mathrm{Chu}_{10}$ according to $\mathrm{Ku}$ sel-Fetzmann \& Schagerl 1992 and modifications like $0.5 \mathrm{~N}, 5 \mathrm{~N}+0.5 \mathrm{P}$ and $10 \mathrm{~N}$ on a weight basis) at different light conditions were added $\left(150 \mu \mathrm{E} \mathrm{m}^{-2} \mathrm{~s}^{-1}\right.$ and $60 \mu \mathrm{E} \mathrm{m}^{-2} \mathrm{~s}^{-1}$, respectively). Details are given in Donabaum (1992).

Extraction took place in dim light to minimize formation of artificial cis-trans-isomeres (compare with Schagerl \& Donabaum 2003, this issue). Chromatographic analyses followed Schagerl \& Donabaum (2003, this issue ; HPLC-system Merck-Hitachi ; column Merck Superspher rp-18 250/4 ; precolumn : Merck Lichrospher rp-18 endcapped). For data acquisition, the Merck-Hitachi L-4250 spectrophotometer was used. To check the accuracy of diode array detectors (DAD), absorbance spectra of the L-4250 were compared with those obtained by the DAD's MerckHitachi L-4500 and Hewlett Packard (Agilent) 1100 Series.

Peaks were detected at $440 \mathrm{~nm}$ and identified by cochromatography with authentic standards (DHI Bioproducts, Denmark), their specific absorption maxima, and by comparison with values from the literature (Foppen 1971 ; Mantoura \& Llewellyn 1983, Wright \& Shearer 1984, Wright et al. 1991, Jeffrey et al. 1997). D-6000 HPLC-manager software (Merck) was employed for analyses, nomenclature of pigments followed trivial names. Peak quantification of major pigments with calibration curves (DHI Bioproducts, Denmark) : chl`s-a, -b and -c, neo-, viola- and diadinoxanthin, peridinin, $\alpha$ - and $\beta$-carotene. For lutein and loroxanthin the calibration curve of $\alpha$-carotene was used, for dinoxanthin that of neoxanthin and for anthera- and zeaxanthin that of $ß$-carotene, respectively. Linear regression analyses and analyses of variance (ANOVA) were performed by SPSS 9.0.1. (SPSS inc.). 


\section{Results}

\section{Chlorophyceae}

Absorption spectra of typical pigments are shown in Fig. 4. Pigments detected : chls-a and -b, neoxanthin, loroxanthin, violaxanthin, antheraxanthin, lutein, zeaxanthin, $\alpha-, \beta-, \gamma-$, and cis- $\beta$-carotene (Table 3 ). Chls-a and -b (27\% of chl-a on a weight basis), lutein $(14 \%)$ and neoxanthin $(6 \%)$ were found in high quantities (Table 4). Chl's -a and -b showed highest relation despite of varying light and nutrient supply $\left(r^{2}=0.98\right.$, $\mathrm{n}=73$, Table 4). Other carotenoids were found in traces only, except for Kentrosphaera austriaca which exhibited an equimolar $\alpha / \beta$-carotene ratio (Fig. 1). Loroxanthin was encountered in 11 of the 18 investigated strains. Occasionally detected chl-ides, phaeophytins and phaeophorbides were interpreted as artefacts due to storage or preparation.

Among the charophyceae, $\gamma$-carotene was detected only in antheridia of 4 of the investigated charales (Table 3). The only species with $\gamma$-carotene in sterile specimens, too, was Chara tomentosa. As in the chlo-

Table 1. Cultures used in this study (media receipts according to Kusel-Fetzmann and Schagerl, 1992).

\begin{tabular}{|c|c|c|c|}
\hline species & strain & origin & medium \\
\hline Chlamydomonas segnis ETTL & 05156 & & $\mathrm{FE}$ \\
\hline Chlamydomonas sp. & 05122 & backwater Melk & FE \\
\hline Coelastrum astroideum & 05017 & Schremser Moorbad & $\mathrm{B}$ \\
\hline Eudorina elegans EHRENB. & 05139 & backwater Lobau & FE \\
\hline E. illinoisensis (KOFOID) PASCHER & 05144 & Lake Wallersee & FE \\
\hline Kentrosphaera austriaca PUNCOCHAROVA & 05109 & pool near Mödling & B \\
\hline Kirchneriella obesa (W.WEST) SCHMIEDLE & 05041 & reservoir near Ottenstein & $\mathrm{F}$ \\
\hline Micractinium pusillum FRES. & 05093 & Alte Donau, Vienna & $\mathrm{FE}$ \\
\hline Monoraphidium minutum (NÄG.) KOM.-LEGN. & 05094 & Zwillingsteiche, Vienna & $\mathrm{F}$ \\
\hline Neglectella peisonis SCHAGERL & 05033 & Lake Neusiedler See & $\mathrm{F}$ \\
\hline Oocystis sp. & 05116 & Lake Neusiedler See & $\mathrm{F}$ \\
\hline Pandorina morum (MÜLLER) BORY & 05118 & Lake Neusiedler See & $\mathrm{FE}$ \\
\hline$P$. morum & 05145 & Hohenau & $\mathrm{FE}$ \\
\hline Scenedesmus dimorphus (TURP.)KÜTZ. & 05098 & Alte Donau, Vienna & $\mathbf{F}$ \\
\hline S. quadricauda (TURP.) BREB.. & 05099 & Alte Donau, Vienna & $\mathrm{F}$ \\
\hline$S$. sp. & 05101 & Alte Donau, Vienna & $\mathrm{F}$ \\
\hline Tetraedron minimum (A. BR.) HANSG. & 05092 & Alte Donau, Vienna & FE \\
\hline Yamagishiella unicocca (RAYB. ET STARR) NOZAKI & 05136 & River Thaya & FE \\
\hline Chara globularis THUILLIER & fresh & & \\
\hline Chara hispida WoOD & fresh & & \\
\hline C. polyacantha (A.BR.) BRAUN, RAB. ET STIZENB. & fresh & & \\
\hline C. rudis (A.BR.) LEONARDI & fresh & & \\
\hline C. tomentosa LINNE & fresh & & \\
\hline C. vulgaris LINNE & fresh & & \\
\hline Nitella opaca Ag. & fresh & & \\
\hline Euglena acus EHRENB. & 08037 & Lake Neusiedler See & $\mathrm{E}$ \\
\hline E. gracilis KLEBS & 08025 & backwater Stoppfenreuth & $E$ \\
\hline E. oxyuris SCHMARDA & 08038 & backwater Eckartsau & ER \\
\hline Trachelomonas sp. & 08005 & backwater Regelsbrunn & $\mathrm{E}$ \\
\hline Peridiniopsis borgei LEMM. & fresh & Windradlteich, Vienna & - \\
\hline Phytodinium sp. & 12001 & Neuhauser bog, Mariazell & A \\
\hline
\end{tabular}



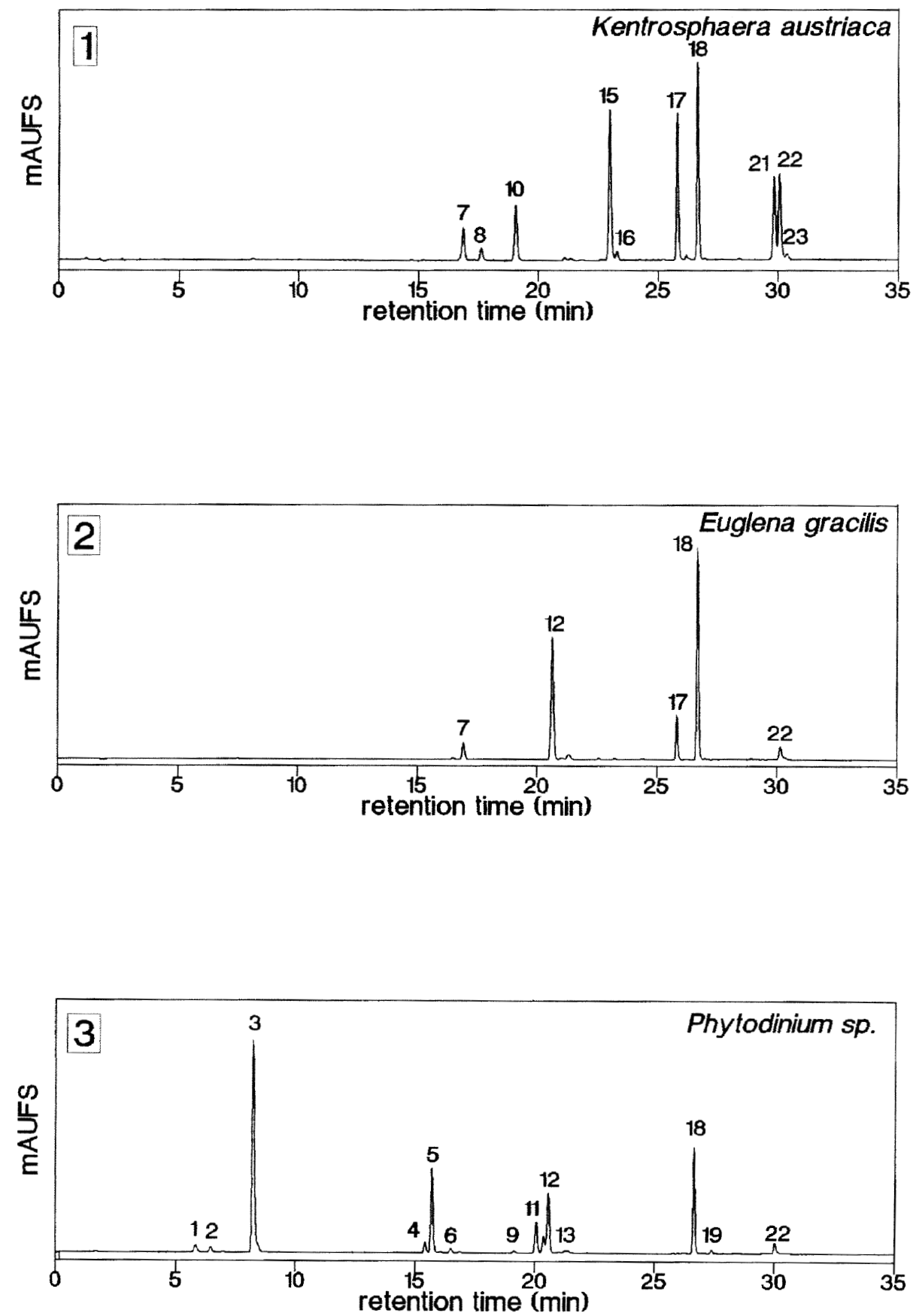

Figs. 1 to 3. Chromatograms of the coccal green alga Kentrosphaera austriaca (1), the euglenophyte Euglena gracilis (2), and the dinophyte Phytodinium sp. (3). Peak numbers according to table 2. 

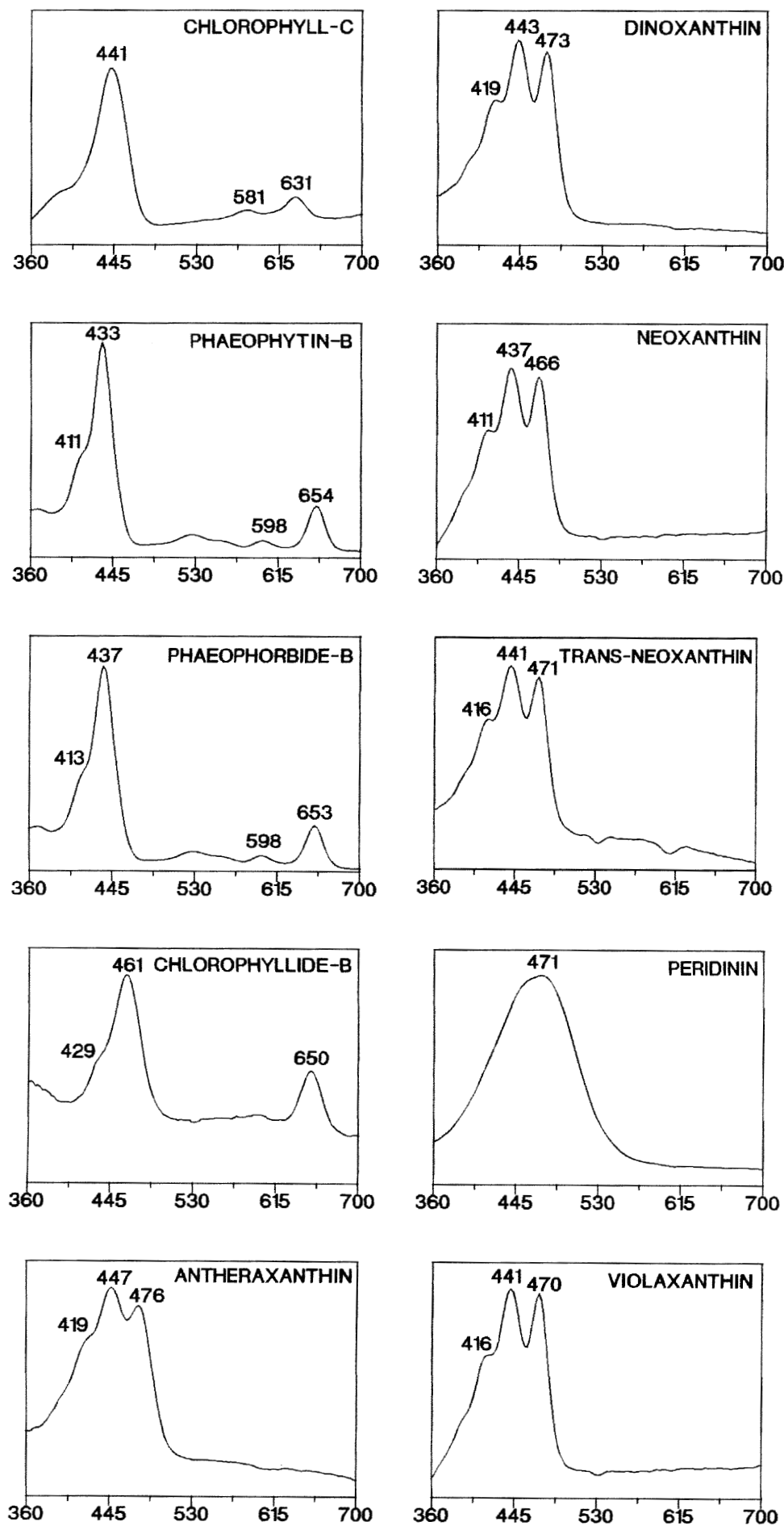

Fig. 4. Absorption spectra of chl-b degradation products and major carotenoids. 
rophyceae, chl-b was highest related to chl-a $\left(\mathrm{r}^{2}=\right.$ $0.98, \mathrm{n}=236$, Table 4 ), being also the main accessory pigment (around $41 \%$ per chl-a on a weight basis). Amounts of lutein (13\%) and neoxanthin (4\%) were comparable to that of chlorophyceae (Table 4).

\section{Euglenophyta}

Pigments detected : chls-a and -b, neoxanthin, diadinoxanthin, diatoxanthin, and $\beta$-carotene. In the investigated specimens, the acetylenic epoxycarotenoid diadinoxanthin was the main xanthophyll which contributed around $75 \%$ to the total carotenoid content. B-carotene, neoxanthin, and diatoxanthin (de-epoxidized diadinoxanthin) were present in minor quantities (Fig. 2, Table 4).

\section{Dinophyta}

Pigments detected : chls-a and $-\mathrm{c}_{2}$, carotenoids P 457 and $\mathrm{P} 468$, peridinol, peridinin, pyrrhoxanthinol, unk- nown dinophyceanpeak I, dinoxanthin, diadinoxanthin, pyrrhoxanthin, echinenone, and B-carotene. Chlsa and $-c_{2}$ were highly abundant.The main carotenoid was peridinin (65\% on weight basis of chl-a, Fig. 3, Table 4), but also diadinoxanthin (25\%) and dinoxanthin ( $13 \%$; neoxanthin with acetylic rest at $\mathrm{C}_{3}$ ) contributed essentially to the pigment content. The pigments mentioned above pigments showed close relations with $r^{2}>0.98(n=23)$; Table 4).Found in minor quantities was $\beta$-carotene ; diatoxanthin was not encountered. The hydrophile carotenoids P 457 and P 468 (nomenclature after Johansen et al. 1974) were also detected (Goodwin and Britton 1988, Jeffrey et al. 1997). Pyrrhoxanthin and pyrrhoxanthinol were identified with reservation. A component close to violaxanthin (dinophyceanpeak I), exhibited a spectrum reminding of peridinin (Tab. 2) and is probably an isomere.

Table 2. Retention times (Rt) and absorption maxima of photosynthetic pigments in the eluent; shoulders of maxima are in brackets.

\begin{tabular}{clcc}
\hline Peak-Nr. & pigment & Rt & maxima in the eluent \\
\hline 1 & carotenoid P 468 & 5.84 & 475 \\
2 & carotenoid P 457 & 6.46 & 463 \\
3 & chl c1+c2 & 8.31 & $441,581,631$ \\
4 & Peridinol & 15.41 & 466 \\
5 & Peridinin & 15.70 & 471 \\
6 & Pyrrhoxanthinol & 16.15 & 457 \\
7 & Neoxanthin & 16.86 & $(411), 437,466$ \\
8 & Loroxanthin & 17.62 & 449,475 \\
9 & Dinophyceenpeak I & 18.81 & 471 \\
10 & Violaxanthin & 19.07 & $(416), 441,470$ \\
11 & Dinoxanthin & 19.96 & $(419), 443,473$ \\
12 & Diadinoxanthin & 20.56 & $(425), 449,477$ \\
13 & Pyrrhoxanthin ? & 20.91 & 461 \\
14 & Antheraxanthin & 21.25 & $(419), 447,476$ \\
15 & Lutein & 22.98 & $(422), 447,475$ \\
16 & Zeaxanthin & 23.30 & $(423), 454,478$ \\
17 & chl-b & 25.83 & $456,596,645$ \\
18 & chl-a & 26.67 & $(408), 428,617,663$ \\
19 & echinenone & 27.37 & 457 \\
20 & $\gamma$-carotene & 29.17 & $(437-439), 460,490$ \\
21 & $\alpha$-carotene & 29.86 & $421,447,474$ \\
22 & B-carotene & 30.08 & $428,453,477$ \\
23 & cis-B-carotene & 30.38 & 448,475 \\
\hline
\end{tabular}




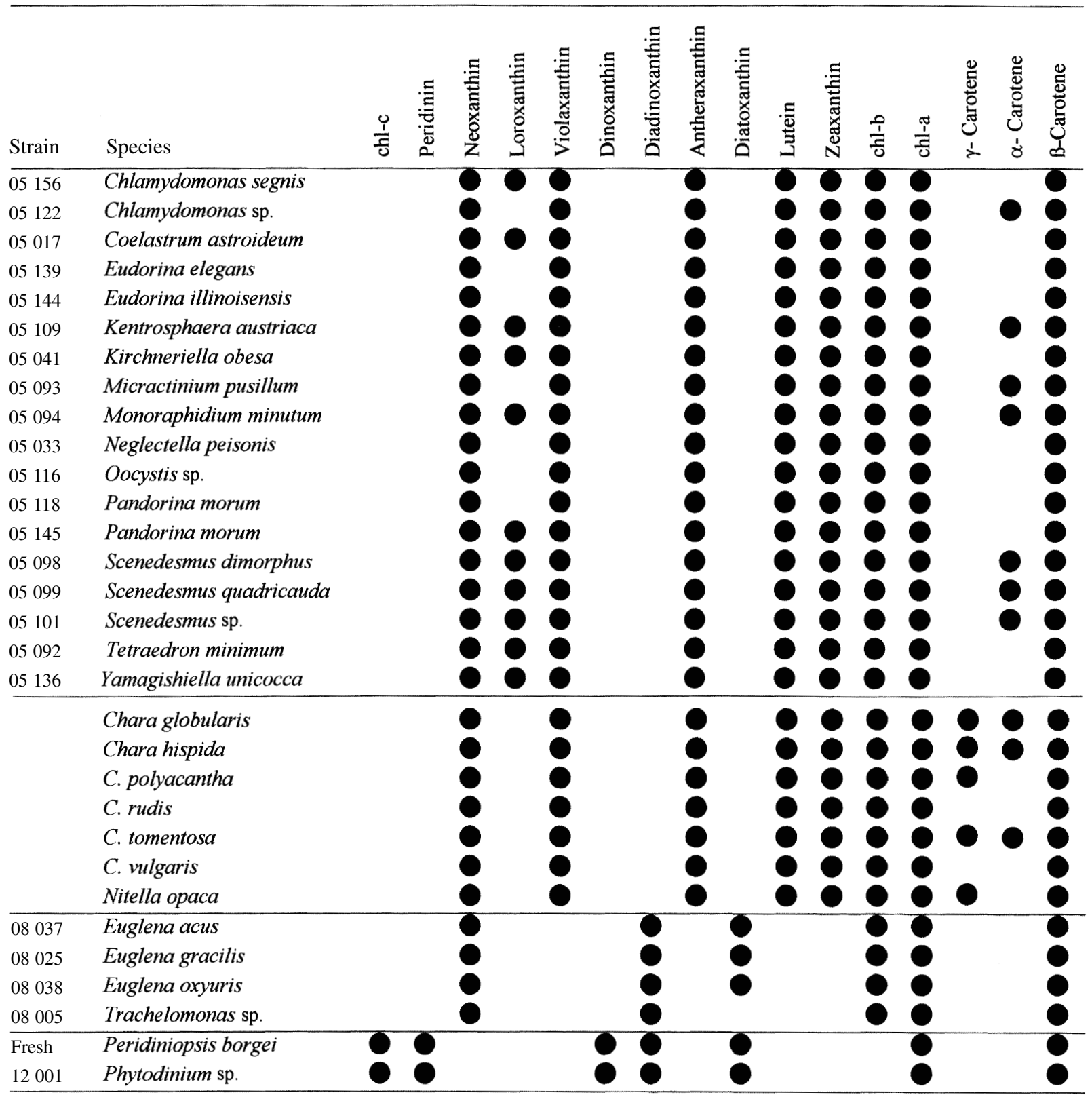


Table 4. Major pigments on basis of chl-a (\% pig ; weight/weight) obtained from linear regression and ANOVA, CD... coefficient of determination, SE.. .standard error, df... degrees of freedom, sign... level of significance.

\begin{tabular}{|c|c|c|c|c|c|c|}
\hline & $\%$ pig & CD & $\mathbf{S E}$ & df & F-value & sign \\
\hline \multicolumn{7}{|l|}{ Chlorophceae } \\
\hline Chl-b & 27.0 & 0.977 & 0.005 & 73 & 3109 & $<0.001$ \\
\hline Neoxanthin & 6.4 & 0.927 & 0.002 & 73 & 908 & $<0.001$ \\
\hline Loroxanthin * & 1.1 & 0.458 & 0.002 & 53 & 44 & $<0.001$ \\
\hline Lutein & 14.4 & 0.861 & 0.007 & 73 & 444 & $<0.001$ \\
\hline Violaxanthin & 3.7 & 0.837 & 0.002 & 73 & 369 & $<0.001$ \\
\hline Antheraxanthin & 0.2 & 0.117 & 0.001 & 73 & 15 & $<0.001$ \\
\hline Zeaxanthin & 0.1 & 0.018 & 0.001 & 73 & 1 & 0.260 \\
\hline$\alpha$-carotene & 0.6 & 0.838 & 0.000 & 73 & 374 & $<0.001$ \\
\hline B-carotene & 3.0 & 0.619 & 0.003 & 73 & 117 & $<0.001$ \\
\hline Charophyceae & & & & 236 & & $<0.001$ \\
\hline Chl-b & 40.7 & 0.980 & 0.004 & 236 & 11487 & $<0.001$ \\
\hline Neoxanthin & 4.2 & 0.710 & 0.002 & 236 & 575 & $<0.001$ \\
\hline Lutein & 12.9 & 0.820 & 0.002 & 236 & 1072 & $<0.001$ \\
\hline Violaxanthin & 2.5 & 0.475 & 0.004 & 236 & 213 & $<0.001$ \\
\hline Antheraxanthin & 0.8 & 0.134 & 0.001 & 236 & 36 & $<0.001$ \\
\hline Zeaxanthin & 0.6 & 0.224 & 0.001 & 236 & 68 & $<0.001$ \\
\hline$\alpha$-carotene $*$ & 0.6 & 0.474 & 0.001 & 116 & 104 & $<0.001$ \\
\hline ß-carotene & 7.7 & 0.114 & 0.014 & 236 & 30 & $<0.001$ \\
\hline$\gamma$-carotene $*$ & 2.3 & 0.007 & 0.019 & 216 & 1 & 0.233 \\
\hline \multicolumn{7}{|c|}{ Euglenophyta (E. acus) } \\
\hline Chl-b & 13.6 & & & & & \\
\hline Neoxanthin & 3.5 & & & & & \\
\hline Diadinoxanthin & 19.1 & & & & & \\
\hline Diatoxanthin & 0.2 & & & & & \\
\hline B-carotene & 2.7 & & & & & \\
\hline \multicolumn{7}{|l|}{ Dinophyta } \\
\hline $\mathrm{Chl}-\mathrm{c}_{2}$ & 56.9 & 0.986 & 0.014 & 23 & 1568 & $<0.001$ \\
\hline Peridinin & 65.1 & 0.989 & 0.015 & 23 & 1973 & $<0.001$ \\
\hline Dinoxanthin & 13.2 & 0.988 & 0.003 & 23 & 1769 & $<0.001$ \\
\hline Diadinoxanthin & 24.6 & 0.997 & 0.003 & 23 & 7831 & $<0.001$ \\
\hline ß-carotene & 3.77 & 0.927 & 0.002 & 23 & 280 & $<0.001$ \\
\hline
\end{tabular}




\section{Discussion}

Remarks on using diode array detectors for pigment determination

In addition to spectrophotometers (UV-VIS) and fluorescence detectors, DAD's are increasingly used in pigment analysis (Wright et al. 1991, Almela et al. 1992, Epler et al. 1992, Kraay et al. 1992, van Heukelem 1992, Tsavalos et al. 1993, Jeffrey et al. 1997, Descy et al 2000). Initially DAD's were developed for the UV range (Meyer 1999). Lately, new DAD types became available allowing also analysis within the VIS-range. For this study, the Merck company kindly placed a Merck L-4500 DAD with DAD-manager software at the author's disposal. This detector covers a range from $190 \mathrm{~nm}$ to $800 \mathrm{~nm}$, detection is by 512 diods in a non-linear way. Resolution is $0.4 \mathrm{~nm}$ at $250 \mathrm{~nm}$, but decreases to $2 \mathrm{~nm}$ at $350 \mathrm{~nm}$, and to $8 \mathrm{~nm}$ at $700 \mathrm{~nm}$. In this detector, a deuterium lamp is used as a light source (low emmission in the VIS range). A second DAD (Hewlett Packard HP 1100) was called in this study, equipped with 1024 diods and a combination of a deuterium and a tungsten lamp to enhance the emmission at larger wavelengths. For comparisons, peaks were recorded using all detectors (Fig. 5). As it showed, peak-identification by the Merck L-4500 is inferior to identification by common spectrophotometers in the longer wave ranges, due to the rather modest quality of the spectra. The poor resolving power in the long wave range is attributable to the non-linear diode detection method as well as to the deuterium light source, which emits powerfully only in the UV-range, thus resulting in pronounced noise in the VIS-range. The second DAD tested in this study recorded spectra of a quality similar to that of UV-VIS-detectors. The Agilent 1100 DAD is a valid alternative to conventional UV-VIS-detectors, not least because it features a high-quality automatic peak purity control. Thus, a combined light source sufficiently emitting in the $>400 \mathrm{~nm}$ range is a precondition for a successful DAD employment in VIS-range analysis.

\section{Chlorophyceae}

Aside from the main pigments which are also characteristic of higher plants, within the prasinophyceae some class-specific pigments such as prasinoxanthin and $\mathrm{Mg}$-2,4-divinyl-phaeoporphyrin-a 5 -monomethylester were observed in previous studies (Ricketts 1966, Foss et al. 1984, Wilhelm et al. 1986, Fawley \& Lee 1990, Fawley 1992), or siphonaxanthin in some orders of the ulvophyceae and prasinophyceae (Kleinig 1969, Weber \& Czygan 1972, Anderson 1983,
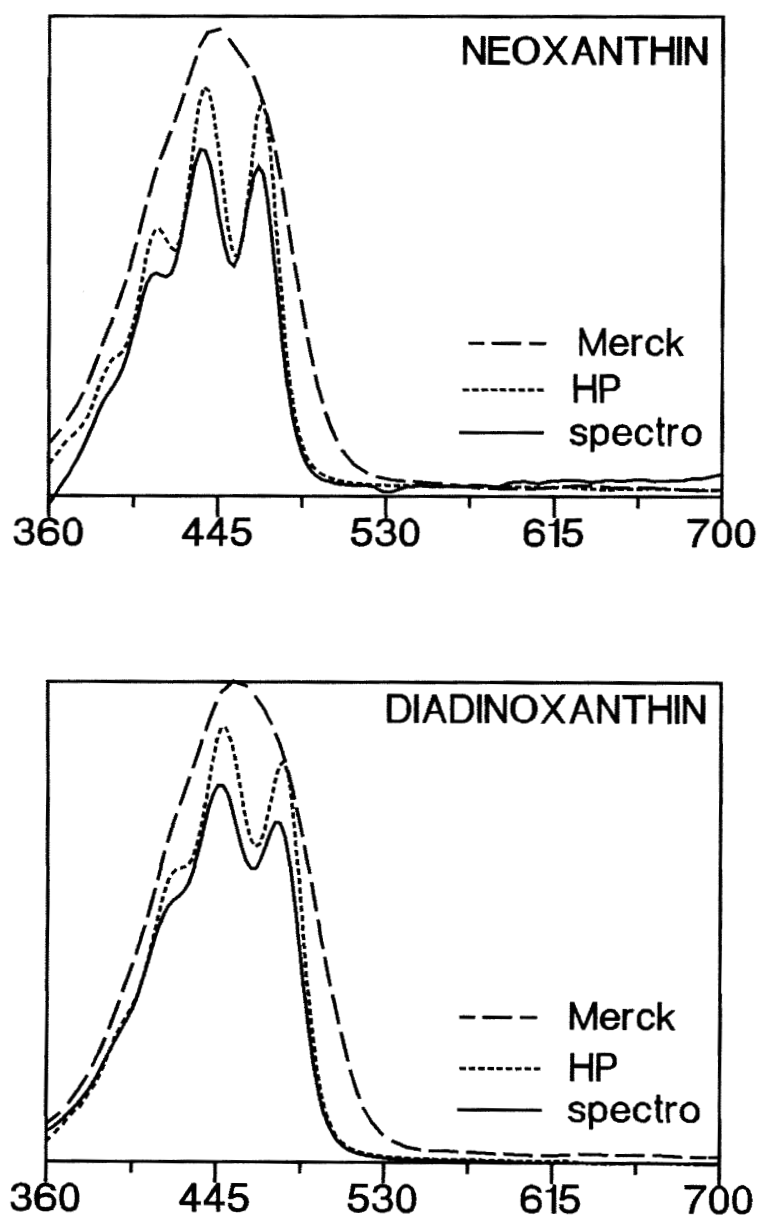

Fig. 5. Overlay of the diode array (HP 1100 and Merck L-4500) and photometer spectra (Merck L-4250) of neoxanthin (top) and diadinoxanthin (bottom)

1985, Chu \& Anderson 1985, Fawley et al. 1990). In this study, none of these carotenoids was encountered in the chlorophyceae, supporting the classification of major lineages within the green algae on basis of molecularbiological and ultrastructural data.

Detected in all of the investigated green algae were chls-a and $-b$, the allenic carotenenoid neoxanthin, the pigments viola-, anthera- and zeaxanthin, which are components of the xanthophyll-cycle (Hager and Stransky 1970a), lutein, as well as $\alpha$ - $\beta$-carotene. Lutein, the main component of the LHC II (Häder 1999) was well separated from zeaxanthin, B-cryptoxanthin and lutein-5-6-epoxide were not detected. Loroxanthin 
being a synonym of pyrenoxanthin, trollein and trihydroxy- $\alpha$-carotene (Aitzetmüller et al. 1969, Nitsche 1974) was encountered in 11 out of 18 chlorophyceae. Initially, high levels of loroxanthin were suspected of being typical of marine deep-water algae, probably substituting for lutein (Yokohama 1982), but further investigations revealed that loroxanthin is not limited to algae growing in deep or shady environments (Yokohama 1983). That loroxanthin is confined only to coccal greens as stated by Goodwin \& Britton (1988), was refuted by a comprehensive study by Fawley (1991), who proved this pigment in several disjunct algal orders. Schagerl \& Angeler (1998) detected loroxanthin in several freshwater volvocales, confirming the taxonomical importance of this carotenoid at the family level. As Schagerl et al. (1999) demonstrated, individual phylogenetic lineages of Pandorina morum syngenes comprise extremely similar sets of traditional characters, including the distribution pattern of the xanthophyll loroxanthin. According to Angeler et al. (1999), loroxanthin randomly occurs in strains of $E$. elegans, too. These results substantiate the currently held hypothesis, that the unique vegetative morphology of these two morphospecies repeatedly has evolved independently at different times.

In this study, secondary carotenoids such as the ketocarotenoids echinenone, canthaxanthin, or astaxanthin (Kessler \& Czygan 1967, Mac Lean 1967, Czygan 1970, Sprey 1970, Deason et al. 1977, Weber \& Wettern 1980, Czygan 1982, Goodwin \& Britton 1988) were not encountered. Synthesis of secondary carotenoids is apparently stimulated by a number of factors, such as nitrogen depletion, excessive supply of light, and high salinity, in particular. Whereas the hypothesis of a relation between secondary carotenoids and loroxanthin (Hager \& Stransky 1970a) needs yet to be veryfied, a definite link exists between secondary carotenoids and the cellular wall component sporopollenin, a carotenoid- or carotenoidester polymer (Atkinson et al. 1972, Burczyk \& Czygan 1983, Rau 1988). Mutants of Chlorella fusca, for instance, which are not capable of ketocarotene synthesis, do not contain sporopollenin in their cellular walls (Burczyk \& Czygan 1983).

Quantitative data obtained in this study fit well into other published studies. Wilhelm et al. (1991) analysed around $10 \%$ lutein per chl-a in the freshwater species Chlorella fusca, in two freshwater species of Scenedesmus between 13 and $17 \%$ lutein were detected (Nicklisch \& Woitke 1999). For chl-b, a constant ratio of 26 to $28 \%$ were observed at varying light supply (Nicklisch \& Woitke 1999), which fit excellent in the range detected in this study (around $27 \%$ on a weight basis of chl-a). However, for marine species like $D u$ naliella tertiolecta, different ratios were found with $19 \%$ chl-b and $31 \%$ lutein (Goericke \& Montoya 1998). In a review table, Mackey et al. (1996) reported for marine chlorophyceae a range of lutein per chl-a being about $0-28 \%$, chl-b per chl-a ranged from 0 to $57 \%$. In the study presented here and also in other investigations quantities of pigments involved in the violaxanthincyclus were below $5 \%$ of chl-a.

\section{Charales}

Only minor attention, so far, was paid to the pigments of stoneworts (Seybold et al. 1941, Andrews et al. 1984, Czeczuga 1986, Howard-Williams et al. 1995, Schagerl \& Pichler 2000). With the exception of Schagerl \& Pichler (2000), who studied pigments by means of HPLC, chl-s and carotenoids have been detected spectrophotometrically in total fraction quality only. Hager \& Stransky (1970a) analyzed pigment extracts by thin layer chromatography. Stoneworts contain the same chloroplast pigments as higher plants with the exception of $\gamma$-car, which was found in antheridia and which is responsible for the red color of vegetative Chara tomentosa specimens. Schagerl \& Pichler (2000) supposed that $\gamma$-car act as a shield against excessive light supply. They suspected the existence of two fractions of $\beta$-car, one fraction being highly correlated with $\gamma$-car and probably located in separate units, the other being independent from $\gamma$-car and to be found in thylakoids. In the present study, chl-b (41\%) as well as lutein $(13 \%)$ were highly correlated to chl-a and act as main light harvesting pigments, whereas other carotenoids showed low quantities only.

\section{Dinophyta}

Phytodinium sp. and Peridiniopsis borgei contain chls-a and -c, most likely chl-c $c_{2}$ as - with the exeption of Exuviella cassubica - this is the only type of chl-c encountered so far in all dinophyceae exhibiting the allenic norcarotenoid peridinin (Jeffrey et al. 1975, Jeffrey 1976). Peridinin is the main carotenoid in all investigated species and it is also the principal component of the LHC II (Haxo et al. 1976, Prezelin 1976, Prezelin and Haxo 1976, Wilhelm 1990). Apparently restricted to this class, peridinin differs from most other carotenoids (tetraterpenes) in exhibiting a $\mathrm{C}_{37^{-}}$ frame, originating from the loss of a $\mathrm{C}_{3}$-group (lactate) out of a tetraterpene (Britton 1988). For marine dinophytes, peridinin content per chl-a ranges from 0 to $106 \%$ (Mackey et al. 1996), Wilhelm et al. (1991) 
found around $38 \%$ in Amphidinium klebsii Kofoid et Swezy. This dinophyte is not a typical freshwater species, but grows in saline and brackish waters. With reservation, pyrrhoxanthin and pyrrhoxanthinol were identified, acetylenic components related to peridinin and peridinol, respectively.

Additionally, B-carotene, the allenic xanthophyll dinoxanthin, and diadinoxanthin were detected, latter being part of the xanthophyll-cycle (Hager 1980). Diatoxanthin, the non-epoxidic derivative of the xanthophyll-cycle (Johansen et al. 1974, Hager 1980, Hallegraeff et al. 1991), was not encountered in this study ; the presence of this carotenoid is largely depending on environmental conditions. The hydrophile carotenoids P 457 und P 468 (Johansen et al. 1974, Goodwin \& Britton 1988) were detected in all studied strains. $\mathrm{P}$ 457 has been shown to be a derivative of neoxanthin containing lactoside in the molecule. Aside from the cyanoprokaryota, this is the only carotenoid-glycoside known in algae (Young \& Britton 1993). The spectral characteristics of one component eluting just before violaxanthin (dinophyceanpeak I) were very similar to peridinin, however, structural analysis would be needed to show if this is actually an isomere.

In a few marine dinophyceae, fucoxanthin replaces peridinin as the main carotenoid component (Mandelli 1968, Thomas \& Cox 1973, Jeffrey et al. 1975). The occurrence of fucoxanthin strictly correlates with the presence of chl- $\mathrm{c}_{1}$ and chl-c $\mathrm{c}_{2}$ (Jeffrey et al. 1975, Jeffrey 1976). According to ultrastructural results, so far, all of these Dinophyceae were found to have two cellular nuclei, exhibiting an eukaryon in addition to the typical dinokaryon (Dodge 1971, Thomas \& Cox 1973). Plastides and eukaryon are supposed to originate from the heterokontophyta (Jeffrey et al. 1975, van den Hoek et al. 1993). In Gyrodinium sp., Bjornland \& Tangen (1979) discovered a previousely unknown main xanthophyll, which differs from peridinin as well as from fucoxanthin.

Pigment patterns and ultrastructural results hint at a multiple origin of the plastides in the dinophyta (van den Hoek et al. 1993, Graham \& Wilcox 2000). The hypothesis of several independent origins of autotrophic dinophyceae is also confimed by the different types of stigmata (inside and outside of the plastides), an otherwise very constant systematic-taxonomical criterion among other classes (Dodge 1969, 1975).

\section{Euglenophyta}

Principal xanthophyll among the studied specimens was diadinoxanthin (Hager \& Stransky 1970b, Liaaen-
Jensen 1985), and not diatoxanthin, as Goodwin \& Britton (1988) or Johannes et al. (1971) maintained. As mentioned above, diadinoxanthin is part of the xanthophyll-cycle (Hager \& Stransky 1970b, Hager 1980) and it is also assumed to be a protective pigment of freshly formed LHC IIs (Brandt \& Wilhelm 1990). Additionally, $\beta$-carotene, neo-, anthera-, and zeaxanthin, and small amounts of diatoxanthin (= de-epoxidized diadinoxanthin) were analyzed. Heteroxanthin (Nitsche 1973) and anhydrodiatoxanthin were not encountered (Liaaen-Jensen 1985). Also not detected in this study were the 3,6-epoxide eutreptiellanone, known from the marine Eutreptiella gymnastica (Fiksdahl et al. 1984), and siphonein, so far isolated from two marine Euglenophyceae (Liaaen-Jensen 1985).

Quantitative data of euglenoid's pigments are unfrequent. In their overview, Mackey et al. (1996) cited $1,5 \%$ neoxanthin per chl-a, $23 \%$ diadinoxanthin and $41 \%$ chl-b of marine types, but without detailed information. Ansotegui et al. (2001) calculated by means of a multifactorial approach (CHEMTAX, Mackey et al. 1996) around 1,5 - 3,0 \% neo-, 4 to $23 \%$ diadinoxanthin and $41-124 \%$ chl-b on a weight basis of chl-a. The same approach was used by Descy et al. (2000), who estimated $20 \%$ diadinoxanthin and 31 to $39 \%$ chl-b per unit chl-a, neoxanthin was not detected. Unfortunately, the initial pigment ratios which are required for CHEMTAX (factor analysis and a steepest descent algorithm) were not cited in these studies.

Especially in marine ecosystems, pigment patterns many a time were used as fingerprints for algal classes. For these class estimations, an initial information i.e. pigment to chl-a ratio must be given to run programs like CHEMTAX. Studies like the one presented here enhance the accuracy of such calculations, they are the headstone for pigment-based algal cummunity structure analyses.

\section{References}

Aitzetmüller K., Strain H.H., Svec W.A., Grandolfo M. \& Katz J.J. 1969. - Loroxanthin, a unique xanthophyll from Scenedesmus obliquus and Chlorella vulgaris. Phytochemistry, 8 : 1761-1770.

Almela L., Fernandez-Lopez J.A. \& Lopez-Roca J.M. 1992. High-performance liquid chromatography-diode array detection of photosynthetic pigments. J. Chromatogr., $607: 215-219$.

Anderson J.M. 1983. - Chlorophyll-protein complexes of a $\mathrm{Co}$ dium species, including a light-harvesting siphonaxanthin-chlorophyll a/b-protein complex, an evolutionary relic of some chlorophyta. Biochim. Biophys. Acta, 724 : 370-380.

Anderson J.M. 1985. — Chlorophyll-protein complexes of a marine green alga, Codium species (Siphonales). Biochim. Biophys. Acta, 806 : 145-153.

Andrews M., Box R., McInroy S. \& Raven J.A. 1984. — Growth of Chara hispida. II. Shade adaptation. J. Ecol., 72, 885-895. 
Angeler D.G., Schagerl M. \& Coleman A.W. 1999. — Phylogenetical relationships between subpopulations of Eudorina elegans (Volvocales, Chlorophyta) inferred from molecular and biochemical data. J. Phycol., $35: 815-823$.

Ansotegui A., Trigueros J.M. \& Orive E. - The use of pigment signatures to assess phytoplankton assemblage structure in estuarine waters. Estuar. Coast. Shelf Sci., 52 : 689-703.

Atkinson A.W., Gunning B.E.S. \& John P.C.L. 1972. — Sporopollenin in the cell wall of Chlorella and other algae : ultrastructure, chemistry, and incorporation of 14c-Acetate, studied in synchronous cultures. Planta (Berl.), $107:$ 1-32.

Bjornland T. \& Tangen K. 1979. - Pigmentation and morphology of a marine Gyrodinium (Dinophyceae) with a major carotenoid different from peridinin and fucoxanthin. J. Phycol., $15: 457-463$.

Brandt P. \& Wilhelm C. 1990. — The light-harvesting system of $E u$ glena gracilis during the cell cycle. Planta (Berl.), 180:293-296.

Britton G. 1988. - Biosynthesis of Carotenoids. In : Goodwin T.W. (Ed.) : Plant pigments. Academic Press, London, San Diego. 133-182.

Burczyk J. \& Czygan F.C. 1983. - Ocurrence of carotenoids and sporopollenin in the cell wall of Chlorella fusca and of its mutants. Z. Pflanzenphysiol., 111 : 169-174.

Chu Z. \& Anderson J.M. 1985. - Isolation and characterization of a siphonaxanthin-chlorophyll a/b-protein complex of photosystem I from a Codium species (Siphonales). Biochim. Biophys. Acta, $806: 154-160$.

Czygan F.-C. 1970. — Untersuchungen über die Bedeutung der Biosynthese von Sekundär-Carotinoiden als Artmerkmal bei Grünalgen. Arch. Mikrobiol., 74 : 77-81.

Deason T.R., Czygan F.-C. \& Soeder D.J. 1977. — Taxonomic significance of secondary carotenoid formation in Neospongiococcum (Chlorococcales, Chlorophyta). J. Phycol., 13 : 176-180.

Descy J.-P., Higgins H.W., Mackey D.J., Hurley J.P. \& Frost T.M. 2000. - Pigment ratios and phytoplankton assessment in northern wisconsin lakes. J. Phycol., $36: 274-286$.

Dodge J.D. 1969. - A review of the fine structure of algal eyespots. Br. phycol. J., 4 : 199-210.

Dodge J.D. 1971. - A dinoflagellate with both a mesocaryotic and a eucaryotic nucleus, I. fine structure of the nuclei. Protoplasma, $73: 145-157$.

Dodge J.D. 1975. - A survey of chloroplast ultrastructure in the Dinophyceae. Phycologia, 4 : 253-263.

Epler K.S., Sander L.C., Ziegler R.G., Wise S.A. \& Craft N.E. 1992. Evaluation of reversed-phase liquid chromatographic columns for recovery and selectivity of selected carotenoids. $J$. Chromatogr., $595: 89-101$.

Fawley M.W. \& Lee C.M. 1990. — Pigment composition of the scaly green flagellate Mesostigma viride (Micromonadophyceae) is similar to that of the siphonous green alga Bryopsis plumosa (U1vophyceae). J. Phycol., 26 : 666-670.

Fawley M.W. 1992. - Photosynthetic pigments of Pseudoscourfieldia marina and select green flagellates and coccoid ultraphytoplankton : implications for systematics of the Micromonadophyceae (Chlorophyta). J. Phycol., $28: 26-31$.

Fawley M.W., Douglas C.A., Stewart K.D. \& Mattox K.R. 1990.Light - harvesting pigment - protein complexes of the Ulvophyceae (Chlorophyta) : Characterization and phylogenetic significance. J. Phycol., $26: 186-195$.

Fawley M. W. 1991. - Disjunct distribution of the xanthophyll loroxanthin in the green algae (Chlorophyta). J. Phycol., 27 : 544-548.

Fiksdahl A., Bjornland T. \& Liaaen-Jensen S. 1984. - Algal carotenoids with novel end groups. Phytochemistry, 23 : 649-655.
Foppen F.H. 1971. - Tables for the identification of carotenoid pigments. Chrom. Rev., 14 (3) : 133-298.

Foss P., Guillard R.R.L. \& Liaaen-Jensen S. 1984. — Prasinoxanthin - a chemosystematic marker for algae. Phytochemistry, 23 : 1629-1633.

Gieskes W.W.C. \& Kraay G.W. 1986a. - Analysis of phytoplankton pigments by HPLC before, during and after mass occurence of the microflagellate Corymbellus aureus during the spring bloom in the open northern North Sea in 1983. Mar. Biol., 92 : 45-52.

Gieskes W.W.C. \& Kraay G.W. 1986b. - Floristic and physiological differences between the shallow and the deep nanophytoplankton community in the euphotic zone of the open tropical Atlantic revealed by HPLC analysis of pigments. Mar. Biol., 91 : 576-576.

Goericke R. 1998. — Response of phytoplankton community structure and taxon-specific growth rates to seasonally varying physical forcing in the Sargasso Sea of Bermuda. Limnol. Oceanogr., $43: 921-935$.

Goericke R. \& Montoya J.P. 1998. — Estimating the contribution of microalgal taxa to chlorophyll a in the field - variations of pigment ratios under nutrient - and light-limited growth. Mar. Ecol. Prog. Ser., 169 : 97-112.

Goodwin T.W. \& Britton G. 1988. - Distribution and analysis of carotenoids. Pages 61-132 in Plant pigments. Goodwin T.W. (Ed.). Academic Press, London, San Diego.

Graham L.E. \& Wilcox L.W. 2000. — Algae. Prentice Hall Inc., $640 \mathrm{pp}+$ Appendix.

Häder D.-P. 1999. — Photosynthese. Thieme Verlag, 270pp.

Hager A. \& Stransky H. 1970a. - Das Carotinoidmuster und die Verbreitung des lichtinduzierten Xanthophyllcyclus in verschiedenen Algenklassen III. Grünalgen. Arch. Mikrobiol., 72 : 68-83.

Hager A. \& Stransky H. 1970b. - Das Carotinoidmuster und die Verbreitung des lichtinduzierten Xanthophyllcyclus in verschiedenen Algenklassen V. Einzelne Vertreter der Cryptophyceae, Euglenophyceae, Bacillariophyceae, Chrysophyceae und Phaeophyceae. Arch. Mikrobiol., 73 : 77-89.

Hager A. 1980. - The reversible, light-induced conversions of xanthophylls in the chloroplast. Pages 57-79 in Pigments in plants. Czygan F.-C. (Ed.). G. Fischer, Stuttgart, New York.

Hallegraeff G.M., Nichols P.D., Volkman J.K., Blackburn S.I. \& Everitt D.A. 1991. - Pigments, fatty acids, and sterols of the toxic Dinoflagellate Gymnodinium catenatum. J. Phycol., 27 : 591-599.

Haxo F.T., Kycia J.H., Somers G.F., Bennett A. \& Siegelman H.W. 1976. - Peridinin-chlorophyll a proteins of dinoflagellate Amphidinium carterae (Plymouth 450). Plant. Physiol., 57 : $297-$ 303.

Howard-Williams C., Schwarz A.-M. \& Vincent W.F. 1995. Deep-water aquatic plant communities in an oligotrophic lake : physiological responses to variable light. Freshwat. Biol., 33, 91-102.

Jeffrey S.W. 1976. - The occurence of chlorophyll c1 and c2 in algae. J. Phycol., 12 : 349-354.

Jeffrey S.W., Mantoura R.F.C. \& Wright S.W. 1997. — Phytoplankton pigments in oceanography. Unesco Publishing, France : $661 \mathrm{pp}$.

Jeffrey S.W., Sielicki M. \& Haxo F.T. 1975. - Chloroplast pigment patterns in Dinoflagellates. J. Phycol., 11 : 374-384.

Johannes B., Brzezinka H. \& Budzikiewicz 1971. — Zur Photosynthese grüner Pflanzen, VI. Isolierung von Diatoxanthin aus Euglena gracilis. Z. Naturforsch., $26: 377-378$.

Johansen J.E., Svec W.A., Liaaen-Jensen S. \& Haxo F.T. 1974. Carotenoids of the Dinophyceae. Phytochemistry, $13: 2261-2271$. 
Kessler E. \& Czygan F.-C. 1967. - Physiologische und biochemische Beiträge zur Taxonomie der Gattungen Ankistrodesmus und Scenedesmus. I. Hydrogenase, Sekundär-Carotinoide und Gelatine-Verflüssigung. Arch. Mikrobiol., 55 : 320-326.

Klein B. \& Sournia A. 1987. — A daily study of the diatom spring bloom at Roscoff (France) in 1985. II. Phytoplankton pigment composition studied by HPLC analysis. Mar. Ecol. Prog. Ser., $37: 265-275$

Kleinig H. 1969. - Carotenoids of siphonous green algae : a chemotxonomical study. J. Phycol., 5 : 281-284.

Kohata K. \& Watanabe M. 1991. - Highly sensitive determination of photosynthetic pigments in marine in situ samples by high-performance liquid chromatography. J. Chromatogr., 558 : 131-140.

Kraay G.W., Zapata M. \& Veldhuis M.J.W. 1992. - Separation of chlorophylls $\mathrm{c} 1, \mathrm{c} 2$, and $\mathrm{c} 3$ of marine phytoplankton by reversed phase - C18 - high - performance liquid chromatography. J. Phycol., $28: 708-712$.

Krause W. 1997. — Charales (Charophyceae). In : Ettl H., Gärtner G., Heynig H. \& Mollenhauer D. (Eds.). Süßwasserflora von Mitteleuropa, Band 18. G. Fischer, 202 pp.

Kusel-Fetzmann E. \& Schagerl M. 1992. — Verzeichnis der Sammlung von Algenkulturen an der Abteilung Hydrobotanik am Institut für Pflanzenphysiologie der Universität Wien. Phyton, 32 209-234.

Latasa M., Landry M.R., Schlüter L. \& Bidigare R.R. 1997. — Pigment-specific growth and grazing rates of phytoplankton in the central equatorial Pacific. Limnol. Oceanogr., 42 : 289-298.

Lee R.E. 1999. - Phycology. Cambridge University Press, $3^{\text {rd }}$ Ed., $614 p p$.

Liaaen-Jensen S. 1985. - Carotenoids of lower plants - recent progress. Pure appl. Chem., $57: 649-658$.

Mackey M.D., Mackey D.J., Higgins H.W. \& Wright S.W. 1996.CHEMTAX - a program for estimating class abundances from chemical markers : application to HPLC measurements of phytoplankton. Mar. Ecol. Prog. Ser., 144 : 265-283.

Mac Lean R. 1967. — Primary and secondary carotenoids of Spongiochloris typica. Physiol. Plant., 20 : 41-47.

Mandelli E.F. 1968. - Carotenoid pigments of the dinoflagellate Glenodinium foliaceum Stein. J. Phycol., 4 : 347-348.

Mandelli E.F. 1969. - Carotenoid interconversion in light - dark cultures of the Dinoflagellate Amphidinium klebsii. J. Phycol., 5 : 382-384

Mandelli E.F. 1972. — The effect of growth illumination on the pigmentation of a marine Dinoflagellate. J. Phycol., $8: 367-369$.

Mantoura R.F.C. \& Llewellyn C.A. 1983. — The rapid determination of algal chlorophyll and carotenoid pigments and their breakdown products in natural waters by reverse - phase high - performance liquid chromatography. Analyt. Chim. Acta, 151 : 297-314.

Meyer V. 1999. — Praxis der Hochleistungsflüssigchromatographie (8. überarbeitete Auflage). Verlag Diesterweg/Salle/Sauerländer, Frankfurt am Main : 293 pp.

Nitsche H. 1974. — Die Identität von Loroxanthin mit Pyrenoxanthin, Trollein und Trihydroxy- $\alpha$-Carotin. Arch. Mikrobiol., 95 79-90.

Nicklisch A. \& Woitke P. 1999. — Pigment content of selected planktonic algae in response to simulated natural light fluctuations and a short photoperiod. Internat. Rev. Hydrobiol., 84 479-495.

Nitsche H. 1973. - Heteroxanthin in Euglena gracilis.- Arch. Mikrobiol 90 : 151-155.

Prezelin B.B. \& Haxo F.T. 1976. - Purification and characterization of peridinin-chlorophyll a-proteins from the marine dinoflagellates Glenodinium sp. and Gonyaulax polyedra. Planta (Berl.), $128: 133-141$.
Prezelin B.B. 1976. - The role of peridinin - chlorophyll-a proteins in the photosynthetic light adaption of the marine Dinoflagellate. Glenodinium sp. Planta (Berl.), $130: 225-233$.

Rau W. 1988. - Functions of Carotenoids other than in photosynthesis. Pages 231-256 in Plant pigments. Goodwin T.W. (Ed.) Academic Press, London, San Diego.

Ricketts T.R. 1966. - Magnesium-2,4-Divinylphaeoporphyrin-a5Monomethylester, a protochlorophyll-like pigment present in some unicellular flagellates. Phytochemistry, $5: 223-229$.

Round F.E. 1985. - The ecology of algae. Reprint of the $1^{\text {st }}$ paperback Ed. Cambridge University Press, 653 pp.

Rowan K.S. 1989. - Photosynthetic pigments of algae. Cambridge University Press, 334pp.

Roy S. 1989. - HPLC-measured chlorophyll-type pigments during a phytoplankton spring bloom in Bedford Basin (Canada). Mar. Ecol. Prog. Ser., 55 : 279-290.

Roy S., Chanut J.P., Gosselin M. \& Sime-Ngando T. 1996. — Characterization of phytoplankton communities in the lower St. Lawrence Estuary using HPLC-detected pigments and cell microscopy. Mar. Ecol. Prog. Ser., 142 : 55-73.

Schagerl M. \& Pichler C. 2000. — Pigment composition of freshwater Charophyceae. Aquatic botany, 67 : 117-129.

Schagerl M. \& Angeler D.G. 1998. - The distribution of the xanthophyll loroxanthin and its systematic sigificance in the colonial Volvocales (Chlorophyta). Phycologia, 37 : 79-83

Schagerl M. \& Donabaum K. 2003. - Patterns of major photosynthetic pigments in freshwater algae. 1. Cyanoprokaryota, Rhodophyta and Cryptophyta. Ann. Limnol. - Int. J. Lim., 39 : 35-47.

Schagerl M., Angeler D.G. \& Coleman A.W. 1999. — Infraspecific phylogeny of Pandorina morum (Volvocales, Chlorophyta) inferred from molecular, biochemical and traditional data. Eur. J. Phycol., 34 : 87-93.

Seybold A., Egle K. \& Hülsbruch W. 1941. — Chlorophyll- und Carotinoidbestimmungen von Süßwasseralgen. Bot. Arch., 42 239-253.

Sommer U. 1998. - Biologische Meereskunde. Springer Verlag, $475 \mathrm{pp}$.

Sprey B. 1970. — Die Lokalisierung von Sekundärcarotinoiden von Haematococcus pluvialis Flotow em. Wille. Protoplasma, 71 235-250.

Thomas R.N. \& Cox E.R. 1973. — The symbiosis of Peridinium balticum (Dinophyceae). I. Ultrastructure and pigment analysis. J. Phycol., (Suppl.) 9: 16.

Tsavalos A.J., Harker M.\& Young A.J. 1993. — Analysis of carotenoids using HPLC with diode-array detection. Europ. Chrom. Anal., 6:9-11.

Van den Hoek C., Jahns H.M., Mann D.G. 1993. — Algen. Thieme Verlag, $411 \mathrm{pp}$

Van Heukelem L., Lewitus A.J., Kana T.D. \& Craft N.E. 1992. High performance liquid chromatography of phytoplankton pigments using a polymeric reversed-phase c18 column. J. Phycol. $28: 867-872$

Veldhuis M.J.W. \& Kraay G.W. 1990. — Vertical distribution and pigment composition of a picoplanctonic prochlorophyte in the subtropical North Atlantic : a combined study of HPLC-analysis of pigments and flow cytometry. Mar. Ecol. Prog. Ser., 68 : 121-127.

Weber A. \& Czygan F.-C. 1972. - Chlorophylle und Carotinoide der Chaetophorineae (Chlorophyceae, Ulotrichales). 1. Siphonaxanthin in Microthamnion kuetzingianum Naegeli. Arch. Mikrobiol., 84 : 243-253.

Weber A. \& Wettern M. 1980. — Some remarks on the usefulness of algal carotenoids as chemotaxonomic markers. Pages 104-116 in Pigments in plants. Czygan F.-C. (Ed.). G. Fischer, Stuttgart, New York. 
Wilhelm C. 1990. — The biochemistry and physiology of light-harvesting processes in chlorophyll b- and chlorophyll c-containing algae. Plant. Physiol. Biochem., 28 : 293-306.

Wilhelm C., Lenartz-Weiler I., Wiedemann I. \& Wild A. 1986. The light-harvesting system of a Micromonas species (Prasinophyceae) : the combination of three different chlorophyll species in one single chlorophyll-protein complex. Phycologia, 25 : 304-312.

Wilhelm C., Rudolph I. \& Renner W. 1991. — A quantitative method based on HPLC-aided pigment analysis to monitor structure and dynamics of the phytoplankton assemblage - A study from Lake Meerfelder Maar (Eifel, Germany). Arch. Hydrobiol., 123 : 21-35.
Wright S.W. \& Shearer J.D. 1984. - Rapid extraction and High performance liquid chromatography of chlorophylls and carotenoids from marine phytoplankton. J. Chromatogr., 294 : 281-295.

Wright S.W., Jeffrey S.W., Mantoura R.F.C., Llewellyn C.A., Bjornland T., Repeta D. \& Welschmeyer N.A. 1991. - Improved HPLC method for the analysis of chlorophylls and carotenoids from marine phytoplankton. Mar. Ecol. Prog. Ser., 77 : 183-196.

Yokohama Y. 1982. - The distribution of lutein and its derivatives in marine green algae. Jpn. J. Phycol., $30: 311-317$.

Yokohama Y. 1983. - A xanthophyll characteristics of deep-water green algae lacking siphonaxanthin. Bot. Mar., 26 :45-48.

Young A. \& Britton G. 1993. - Carotenoids in Photosynthesis. Chapman \& Hall, 498 pp. 